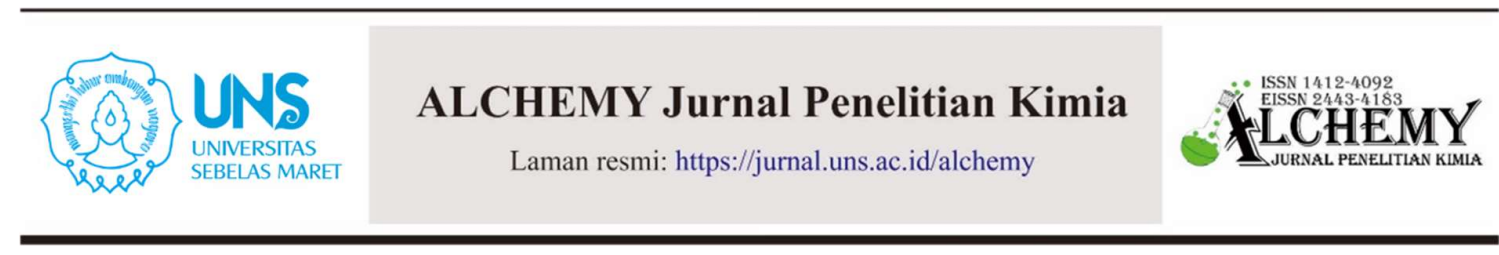

\title{
Kadar Total Fenol dan Flavonoid Ekstrak Temu Kunci (Boesenbergia pandurata) melalui Metode Ekstraksi Microwave
}

\author{
Sadwika Najmi Kautsari ${ }^{*}$, Aji Humaedia ${ }^{\text {, Dian Rachma Wijayanti }{ }^{\text {b }} \text {, Muhammad Safaat }}$ \\ a Prodi S1 Farmasi - Fakultas Sains dan Teknologi - Universitas Binawan, Jl. Kalibata Raya, Cawang, Kramatjati, Jakarta Timur. DKI \\ Jakarta - 13630. Telp. (021) 80880882 \\ ${ }^{\mathrm{b}}$ Prodi D4 Teknologi Laboratorium Medis - Fakultas Sains dan Teknologi - Universitas Binawan, Jl. Kalibata Raya, Cawang, Kramatjati, \\ Jakarta Timur. DKI Jakarta - 13630. Telp. (021) 80880882

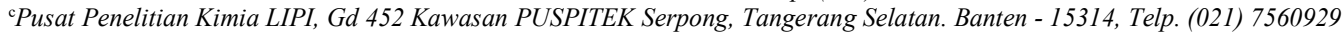

"Corresponding author: sadwika@binawan.ac.id

DOI: 10.20961/alchemy.17.1.46497.96-104

Receive 08 August 2020, Accepted 19 February 2021, Published 08 March 2021

Kata kunci:

ekstraksi;

fenol;

flavonoid;

microwave;

temu kunci.

\begin{abstract}
ABSTRAK. Temu kunci (Boesenbergia pandurata) merupakan tanaman yang memiliki kandungan flavonoid dan fenol serta banyak dimanfaatkan sebagai obat tradisional. Namun, hingga kini temu kunci belum pernah diekstraksi dengan metode ekstraksi menggunakan microwave. Ekstraksi dengan menggunakan microwave memiliki potensi yang baik untuk dikembangkan pada temu kunci sehingga dapat dihasilkan ekstrak temu kunci yang memiliki kadar total fenol dan flavonoid yang tinggi dengan waktu ekstraksi yang lebih sedikit. Oleh karena itu, penelitian ini bertujuan untuk mengetahui kadar total fenol dan flavonoid ekstrak temu kunci yang diekstraksi dengan menggunakan microwave pada berbagai variasi waktu. Pembuatan ekstrak temu kunci dilakukan dengan meradiasi temu kunci dalam campuran etanol $70 \%$ pada tipe pemanasan Low selama 15 menit yang dibandingkan dengan tipe pemanasan Medium selama 3, $5,7,9$, dan 12 menit. Berdasarkan penelitian, rendemen yang dihasilkan berkisar antara 5,91\% - 9,7\%. Kadar total fenol yang dihasilkan berkisar antara $6,69 \%-9,18 \%$, sedangkan kadar flavonoid berkisar antara $13,46 \%-21,41 \%$. Rendemen ekstrak temu kunci semakin meningkat dengan waktu ekstraksi yang lebih lama dan suhu yang lebih tinggi. Kadar total fenol dan flavonoid tertinggi adalah pada tipe pemanasan Medium selama 7 menit pada suhu $57^{\circ} \mathrm{C}$.
\end{abstract}

Keywords:

ABSTRACT. Total Phenol and Flavonoid Content of Fingerroot (Boesenbergia pandurata) by Microwave Assisted Extraction. Fingerroot (Boesenbergia pandurata) is a plant that contains flavonoids and phenols. It is often used as traditional medicine. However, fingerroot has never been extracted using a microwave-assisted extraction method. In fact, extraction using microwave has good potential to be developed so that the fingerroot extracts can be produced which have high levels of total phenols and flavonoids with less extraction time. Therefore, this study aims to determine the total phenol and flavonoids extracted by microwave at various times. The preparation of fingerroot extract was carried out by irradiated fingerroot in $70 \%$ ethanol mixture on Low heating type for 15 minutes, compared to Medium heating type for $3,5,7,9$, and 12 minutes. Based on the research, the yield produced ranged from $5.91 \%-9.7 \%$. The total phenol content produced ranged from $6.69 \%-9.18 \%$, while the levels of flavonoids ranged from $13.46 \%-21.41 \%$. The yield of fingerroot extract increased with longer extraction time and higher temperature. The highest total phenol and flavonoid levels were the Medium heating type for 7 minutes at $57^{\circ} \mathrm{C}$.

\section{PENDAHULUAN}

Temu kunci (Boesenbergia pandurata) merupakan tanaman dari famili Zingiberaceae yang banyak digunakan sebagai bumbu pada masakan Indonesia. Selain itu, temu kunci juga dimanfaatkan sebagai obat tradisional, misalnya untuk mengobati ketidaknyamanan lambung, diare, infeksi jamur, dan peradangan pada uterus wanita (Chahyadi et al., 2014) Berdasarkan skrining fitokimia, ekstrak temu kunci banyak mengandung senyawa flavonoid, alkaloid, dan fenolik (Jitvaropas et al., 2012). Flavonoid utama yang terdapat pada ekstrak temu kunci adalah kalkon, flavanon, dan flavon (Chahyadi et al., 2014). Senyawa-senyawa tersebut berpotensi secara signifikan dalam memberikan perlindungan antioksidan terhadap kerusakan oksidatif yang disebabkan oleh radikal bebas dan memiliki sifat antimikroba yang kuat (Chahyadi et al., 2014; Jitvaropas et al., 2012).

Ekstraksi senyawa bioaktif dari rimpang temu kunci yang pernah dilakukan pada satu dekade terakhir sebagian besar terfokus pada proses ekstraksi secara konvensional, misalnya dengan maserasi (Atun et al., 2018; 
Jitvaropas et al., 2012; Limsuwan and Voravuthikunchai, 2013), soxhlet (Sukandar and Sunderam, 2014), dan refluks (Sukandar et al., 2015). Teknik ekstraksi tersebut memiliki beberapa kelemahan, antara lain dibutuhkannya banyak pelarut, waktu ekstraksi yang lama, evaporasi pelarut dalam jumlah banyak, dekomposisi termal pada senyawa yang termolabil, dan selektivitas ekstraksi yang rendah (Azmir et al., 2013). Pada penelitian lainnya, kadar flavonoid dan total fenol temu kunci yang berasal dari metode ekstraksi maserasi masing-masing adalah sebesar 24,71 mgQE/g (Hati et al., 2019) dan 8,245\% (Melannisa et al., 2011). Berdasarkan hal tersebut, untuk mengatasi keterbatasan pada metode ekstraksi konvensional temu kunci, perlu dilakukan ekstraksi dengan metode yang lebih ramah lingkungan dan tetap berhasil baik.

Beberapa metode ekstraksi non-konvensional yang pernah diteliti untuk ekstraksi senyawa bioaktif dari tanaman antara lain ekstraksi dengan bantuan microwave, ultrasonikasi, medan listrik statis, maupun dengan bantuan enzim (Azmir et al., 2013). Namun, hingga saat ini belum ada penelitian mengenai ekstraksi senyawa fenol dan flavonoid temu kunci dengan bantuan microwave. Padahal, diantara metode ekstraksi non-konvensional tersebut ekstraksi melalui microwave tergolong metode ekstraksi yang menjanjikan dalam menghasilkan senyawa bioaktif. Teknik ini dinilai dapat mempersingkat waktu ekstraksi, meminimalisir penggunaan pelarut, dan biaya ekstraksi yang lebih rendah (Dahmoune et al., 2015).

Selain itu, metode ini digolongkan sebagai green techniques karena memenuhi beberapa poin dari standar kimia hijau, antara lain penggunaan sampel dan pelarut organik dengan jumlah yang lebih sedikit, pengurangan volume limbah hasil penelitian, serta efisiensi waktu dan biaya (Azmir et al., 2013; Gałuszka et al., 2013). Metode ekstraksi dengan microwave juga akan menghasilkan rendemen, kadar total fenol, dan flavonoid yang lebih tinggi (Vieira et al., 2017). Kadar total fenol dan flavonoid yang tinggi akan mengakibatkan aktivitas antioksidan menjadi lebih kuat (Hilma et al., 2020). Berdasarkan latar belakang di atas, penelitian ini bertujuan untuk mengetahui kadar flavonoid dan total fenol yang dihasilkan dari proses ekstraksi temu kunci menggunakan ekstraksi dengan bantuan microwave pada variasi waktu tertentu.

\section{METODE PENELITIAN}

\section{Alat dan Bahan}

Bahan yang digunakan yaitu simplisia temu kunci (Boesenbergia pandurata) yang didapatkan dari Balai Penelitian Tanaman Rempah dan Obat (Balittro), akuades, etanol 96\% (teknis), metanol, asam galat (Merck), Folin-Ciocalteu (Merck), $\mathrm{Na}_{2} \mathrm{CO}_{3}$ (Merck), kuersetin (Sigma-Aldrich), $\mathrm{AlCl}_{3}$ (Merck), $\mathrm{NaOH}$ (Merck), dan $\mathrm{NaNO}_{2}$ (Merck). Alat-alat yang digunakan antara lain evaporator (Ogawa), microwave (Sharp R200J(S)), dan spektrofotometer UV-Vis (Agilent Technologies Cary 60). Evaporator dikondisikan pada suhu $50{ }^{\circ} \mathrm{C}$ dan tekanan vakum $72 \mathrm{cmHg}$, sedangkan microwave memiliki daya 450 Watt.

\section{Pembuatan Ekstrak Temu Kunci (Boesenbergia pandurata)}

Sebanyak $100 \mathrm{~g}$ serbuk simplisia ditambahkan dengan $300 \mathrm{~mL}$ etanol 70\%. Selanjutnya campuran dilakukan pengadukan secara manual selama 5 menit dan diradiasi menggunakan microwave. Waktu radiasi dilakukan selama 15 menit pada tipe pemanasan Low, sedangkan pada tipe pemanasan Medium radiasi dilakukan pada menit ke 3, 5, 7, 9, dan 12 yang disertai dengan pengukuran suhu setelah waktu radiasi berakhir. Selanjutnya hasil ekstraksi didinginkan pada suhu ruang dan dilakukan penyaringan dengan menggunakan kertas saring Whatman. Kemudian simplisia hasil ekstraksi ditambahkan dengan $200 \mathrm{~mL}$ etanol 70\%, dilakukan pengadukan manual selama 5 menit, dan disaring dengan menggunakan kertas saring. Proses tersebut dilakukan sebanyak dua kali sehingga total etanol 70\% yang digunakan dalam proses ekstraksi adalah $700 \mathrm{~mL}$. Proses ekstraksi dilakukan secara bertingkat dengan tujuan supaya senyawa yang terekstraksi menjadi lebih banyak. Selanjutnya filtrat hasil ekstraksi dikumpulkan pada masing-masing perlakuan dan dipekatkan menggunakan evaporator pada suhu $50{ }^{\circ} \mathrm{C}$ hingga diperoleh ekstrak kental. Kemudian dilakukan perhitungan rendemen (persamaan (1)), dengan membandingkan antara massa ekstrak pekat yang diperoleh dengan massa simplisia yang digunakan (Kautsari et al., 2020).

$$
\text { Rendemen }=\frac{\text { massa ekstrak }}{\text { massa simplisia }} \times 100 \%
$$

\section{Pembuatan Kurva Kalibrasi Standar Asam Galat}

Kandungan senyawa fenol total dalam ekstrak ditentukan dengan metode Folin-Ciocalteu menggunakan asam galat sebagai standar. Asam galat dibuat larutan induk terlebih dahulu dengan dilarutkannya $1 \mathrm{mg}$ asam galat 
dalam $1 \mathrm{~mL}$ metanol $(1000 \mu \mathrm{g} / \mathrm{mL})$. Selanjutnya larutan induk asam galat dibuat serial konsentrasi hingga diperoleh konsentrasi akhir 5, 10, 20, 30 dan $40 \mu \mathrm{g} / \mathrm{mL}$. Larutan tersebut masing-masing dimasukkan ke dalam tabung reaksi dan ditambahkan akuades hingga volumenya menjadi 4 mL. Kemudian campuran ditambahkan 250 $\mu \mathrm{L}$ Folin-Ciocalteu, dikocok hingga homogen dan didiamkan selama 8 menit. Selanjutnya ditambahkan $750 \mu \mathrm{L}$ $\mathrm{Na}_{2} \mathrm{CO}_{3} 20 \%$, dikocok sampai homogen, didiamkan selama 2 jam pada suhu kamar dan absorbansi diukur pada panjang gelombang $765 \mathrm{~nm}$. Pengukuran dilakukan sebanyak 2 kali pengulangan. Kemudian dibuat kurva kalibrasi dengan menghubungkan nilai konsentrasi larutan standar sebagai absis (x) dan absorbansi sebagai ordinat (y).

\section{Pengukuran Kadar Total Fenol Ekstrak Temu kunci}

Pengukuran kadar total fenol dilakukan dengan cara dilarutkannya sampel ekstrak sebanyak 4 mg ke dalam 4 $\mathrm{mL}$ metanol hingga diperoleh konsentrasi induk sampel $1000 \mu \mathrm{g} / \mathrm{mL}$. Sebanyak $500 \mu \mathrm{L}$ larutan sampel ditambahkan akuades hingga volumenya menjadi $4 \mathrm{~mL}$. Kemudian campuran ditambahkan $250 \mu \mathrm{L}$ FolinCiocalteu, dikocok hingga homogen dan didiamkan selama 8 menit. Selanjutnya ditambahkan $750 \mu \mathrm{L} \mathrm{Na}_{2} \mathrm{CO}_{3}$ $20 \%$, dikocok sampai homogen, didiamkan selama 2 jam pada suhu kamar dan absorbansi diukur pada panjang gelombang $765 \mathrm{~nm}$. Pengukuran dilakukan sebanyak 2 kali pengulangan. Kadar total fenol pada ekstrak dihitung dengan menggunakan persamaan (2).

$$
\text { Kadar Total Fenol dalam Ekstrak }(\%)=\frac{\frac{(\text { Absorbansi sampel }- \text { intersep })}{\text { slope }} \times \mathrm{fp}}{\text { Konsentrasi awal }} \times 100 \%
$$

\section{Pembuatan Kurva Kalibrasi Standar Kuersetin}

Kuersetin ditimbang sebanyak $4 \mathrm{mg}$ dilarutkan dalam $4 \mathrm{~mL}$ metanol (larutan induk $1000 \mu \mathrm{g} / \mathrm{mL}$ ). Kemudian dibuat serangkaian larutan standar $10 \mu \mathrm{g} / \mathrm{mL}, 20 \mu \mathrm{g} / \mathrm{mL}, 30 \mu \mathrm{g} / \mathrm{mL}, 40 \mu \mathrm{g} / \mathrm{mL}$, dan $50 \mu \mathrm{g} / \mathrm{mL}$ dengan cara pengenceran larutan induk. Larutan standar kuersetin sebanyak masing-masing 50, 100, 150, 200, dan 250 $\mu \mathrm{L}$ dimasukkan ke dalam tabung reaksi. Kemudian ditambahkan $2 \mathrm{~mL}$ akuades dan $150 \mu \mathrm{L} \mathrm{NaNO}_{2}$ 5\%. Setelah 5 menit, ditambahkan $150 \mu \mathrm{L} \mathrm{AlCl}_{3}$ 10\%. Enam menit kemudian, ditambahkan $2 \mathrm{~mL} \mathrm{NaOH} 1 \mathrm{M}$ dengan akuades hingga volume menjadi $5 \mathrm{~mL}$. Selanjutnya larutan dihomogenkan dan diukur absorbansinya pada panjang gelombang $510 \mathrm{~nm}$ dengan spektrofotometer UV-Vis. Tahap berikutnya dibuat kurva kalibrasi antara nilai konsentrasi larutan standar sebagai absis (x) dan absorbansi sebagai ordinat (y).

\section{Pengukuran Kadar Flavonoid Total Ekstrak Temu Kunci}

Sampel ekstrak dibuat dengan cara $4 \mathrm{mg}$ sampel dilarutkan ke dalam $4 \mathrm{~mL}$ metanol (konsentrasi setara dengan $1000 \mu \mathrm{g} / \mathrm{mL}$ ). Kemudian $500 \mu \mathrm{L}$ larutan sampel ditambahkan dengan akuades sehingga diperoleh konsentrasi akhir $100 \mu \mathrm{g} / \mathrm{mL}$. Langkah selanjutnya diperlakukan sama dengan larutan standar. Pengenceran dilakukan sebanyak 10 kali. Kadar total flavonoid dihitung dengan menggunakan persamaan (3).

$$
\text { Kadar Total Flavonoid dalam Ekstrak }(\%)=\frac{\frac{(\text { Absorbansi sampel }- \text { intersep })}{\text { slope }} \times \mathrm{fp}}{\text { Konsentrasi awal }} \times 100 \%
$$

\section{HASIL DAN PEMBAHASAN \\ Rendemen Ekstrak}

Pada penelitian ini digunakan etanol 70\% sebagai pelarut pengekstraksi karena etanol $70 \%$ akan menghasilkan rendemen yang lebih banyak untuk senyawa bioaktif daripada etanol dengan konsentrasi lainnya. Menurut Elboughdiri (2018), pelarut etanol 70\% akan menghasilkan rendemen ekstrak bahan alam yang lebih tinggi daripada etanol 50\%,60\%, dan $80 \%$ melalui ekstraksi maserasi. Air memiliki gugus -OH yang bersifat polar sehingga dapat melarutkan senyawa ion, yaitu berupa kation dan anion, sedangkan etanol merupakan pelarut yang bersifat semi polar dan dapat membentuk ikatan hidrogen antara molekul-molekulnya. Oleh karena itu, campuran antara etanol dengan air pada konsentrasi tertentu yaitu 70\% akan mengakibatkan senyawa yang terekstrak menjadi lebih banyak (Sa'adah and Nurhasnawati, 2015).

Rendemen ekstrak temu kunci yang dihasilkan pada tipe pemanasan Low selama 15 menit adalah sebesar 5,91\%, sedangkan pada tipe pemanasan Medium pada menit ke 3, 5, 7, 9, dan 12 secara berturut-turut adalah 5,84; 6,$20 ; 7,49 ; 8,25$; dan 9,70\% (Tabel 1). Hal tersebut menunjukkan bahwa semakin lama waktu dan tinggi suhu ekstraksi microwave maka rendemennya juga semakin tinggi. Hal ini sesuai dengan penelitian ekstraksi menggunakan microwave sebelumnya, yaitu rendemen ekstraksi yang tinggi dapat dihasilkan oleh waktu ekstraksi 
yang lebih lama (Rajkovic et al., 2016). Selain itu, pada penelitian lainnya dengan menggunakan Juglans regia, rendemen ekstrak yang dihasilkan dengan menggunakan ekstraksi microwave serta pelarut etanol $60,2 \%$ akan menghasilkan rendemen hingga $44,3 \%$ pada menit ke 34,6 dan suhu $180^{\circ} \mathrm{C}$ (Vieira et al., 2017).

Tabel 1. Rendemen ekstrak temu kunci.

\begin{tabular}{lccc}
\hline Tipe Pemanasan & Waktu Ekstraksi & Suhu $\left({ }^{\circ} \mathbf{C}\right)$ & Rendemen (\%) \\
\hline Low & 15 menit & 43 & 5,91 \\
\hline & 3 menit & 38 & 5,84 \\
Medium & 5 menit & 46 & 6,20 \\
& 7 menit & 57 & 7,49 \\
& 9 menit & 61 & 8,25 \\
& 12 menit & 73 & 9,70 \\
\hline
\end{tabular}

Mekanisme ekstraksi microwave diperkirakan melibatkan 3 langkah, antara lain pemisahan zat aktif dari matriks sampel pada suhu dan tekanan yang meningkat secara drastis, peningkatan penetrasi pelarut ke dalam matriks sampel, dan pelepasan zat aktif dari matriks sampel menuju pelarut. Jadi, pada ekstraksi dengan bantuan microwave, mekanisme transfer bertindak dalam arah yang sinergis satu sama lain sehingga mengakibatkan percepatan waktu ekstraksi (Kala et al., 2016). Oleh sebab itu, semakin lama waktu ekstraksi, maka rendemen yang dihasilkan akan semakin tinggi. Namun, rendemen hasil ekstraksi yang tinggi belum tentu berkorelasi positif terhadap komponen senyawa bioaktif yang diinginkan karena pada rendemen yang tinggi tersebut dapat saja memiliki kandungan metabolit primer (polisakarida, protein, lipid) yang besar dan menurunkan persentase komponen metabolit sekunder senyawa bioaktif (Rajkovic et al., 2016). Metabolit primer seperti karbohidrat dan protein dapat terlarut dalam pelarut etanol 80\% (López-Perea et al., 2019), sedangkan lipid sulit terlarut dalam pelarut yang polar (Silve et al., 2018).

\section{Penetapan Kadar Total Fenol}

Pada penelitian ini, penentuan kadar total fenol pada sampel digunakan asam galat sebagai larutan standar. Asam galat termasuk golongan asam fenol sederhana dan merupakan senyawa fenolik turunan asam hidroksibenzoat. Penggunaan asam galat sebagai larutan standar disebabkan karena asam galat merupakan senyawa fenol yang stabil, memiliki kelarutan yang tinggi, dan relatif lebih murah dibandingkan senyawa lainnya (Ahmad et al., 2015; Bastola et al., 2017).

Asam galat maupun ekstrak direaksikan dengan reagen Folin-Ciocalteu yang merupakan campuran dari asam fosfotungstat $\left(\mathrm{H}_{3} \mathrm{PW}_{12} \mathrm{O}_{40}\right)$ dan asam fosfomolibdat $\left(\mathrm{H}_{3} \mathrm{PMo}_{12} \mathrm{O}_{40}\right)$ sehingga menghasilkan warna kuning yang merupakan tanda bahwa sampel mengandung senyawa fenol. Selanjutnya campuran tersebut ditambahkan $\mathrm{Na}_{2} \mathrm{CO}_{3}$ yang berfungsi sebagai pengarah suasana basa sehingga terbentuk oksotungstat dan oksomolibdat, serta terjadi disosiasi proton pada senyawa fenolik menjadi ion fenolat yang ditandai dengan dihasilkannya warna biru pada sampel. Semakin besar kadar total fenol dalam suatu ekstrak maka akan menghasilkan warna biru yang semakin pekat (Ahmad et al., 2015; Lamuela-Raventós, 2017; Ngibad and Lestari, 2020). Metode Folin-Ciocalteu yang digunakan untuk menentukan kadar total fenol memiliki beberapa kelebihan, antara lain mudah dan cepat dilakukan, serta tidak membutuhkan reagen yang mahal maupun instrumentasi yang terlampau canggih (Ford et al., 2019).

Tabel 2. Hasil pengukuran absorbansi larutan standar asam galat.

\begin{tabular}{cccc}
\hline \multirow{2}{*}{ Konsentrasi $(\boldsymbol{\mu g} / \mathbf{m l})$} & \multicolumn{3}{c}{ Absorbansi ke- } \\
\cline { 2 - 4 } & $\mathbf{1}$ & $\mathbf{2}$ & Rata-rata \\
\hline 0 & 0,0053 & 0,0063 & 0,0058 \\
5 & 0,3845 & 0,3862 & 0,3854 \\
10 & 0,8102 & 0,8159 & 0,8131 \\
20 & 1,6678 & 1,7937 & 1,7308 \\
30 & 2,7932 & 2,8494 & 2,8213 \\
40 & 4,9936 & 4,2102 & 4,6019 \\
\hline
\end{tabular}

Hasil pengukuran absorbansi larutan standar asam galat pada panjang gelombang $765 \mathrm{~nm}$ dapat dilihat pada Tabel 2. Berdasarkan tabel tersebut dibuat kurva kalibrasi hubungan antara konsentrasi standar asam galat dan absorbansi, sehingga diperoleh persamaan regresi $y=0,1113 x-0,2207$, nilai koefisien determinasi $\left(R^{2}\right)=0,976$, 
dan koefisien korelasi $(r)=0,988$ (Gambar 1). Nilai $\mathrm{R}^{2}=0,976$ memiliki arti 97,6\% absorbansi dipengaruhi oleh konsentrasi, sedangkan nilai $\mathrm{r}=0,988$ menunjukan terdapat hubungan yang erat antara konsentrasi dan absorbansi. Semakin besar konsentrasi maka absorbansinya akan semakin besar.

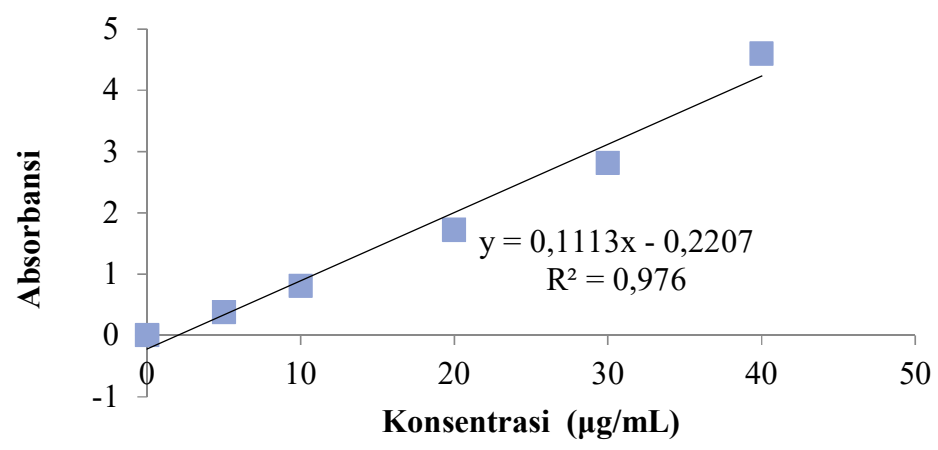

Gambar 1. Kurva kalibrasi standar asam galat pada panjang gelombang $765 \mathrm{~nm}$.

Persamaan regresi linear yang diperoleh pada Gambar 1 digunakan untuk menentukan kadar total fenol ekstrak dengan cara memasukkan nilai absorbansi dari ekstrak temu kunci ke dalam persamaan tersebut. Berdasarkan penelitian, pada waktu ekstraksi 15 menit dengan tipe pemanasan Low diperoleh kadar total fenol ekstrak temu kunci sebesar 7,72 $\pm 0,28 \%$. Adapun ketika menggunakan tipe pemanasan Medium dengan waktu ekstraksi 3, 5, 7, 9, dan 12 menit, didapatkan kadar total fenol secara berurutan sebesar $6,69 \pm 0,18 ; 7,72 \pm 0,23 ; 9,18$ $\pm 0,3 ; 8,23 \pm 0,15$; dan $8,77 \pm 0,11 \%$ (Tabel 3).

Tabel 3. Kadar total fenol ekstrak temu kunci melalui ekstraksi microwave pada beberapa waktu ekstraksi.

\begin{tabular}{|c|c|c|c|c|c|c|}
\hline $\begin{array}{l}\text { Tipe } \\
\text { Pemanasan }\end{array}$ & $\begin{array}{c}\text { Waktu } \\
\text { Ekstraksi }\end{array}$ & $\begin{array}{l}\text { Suhu } \\
\left({ }^{\circ} \mathrm{C}\right)\end{array}$ & Ulangan & Absorbansi & $\begin{array}{c}\text { Kadar Total } \\
\text { Fenol Ekstrak } \\
(\%) \\
\end{array}$ & $\begin{array}{c}\text { Rerata Kadar } \\
\text { Total Fenol } \\
\text { Ekstrak (\%) }\end{array}$ \\
\hline \multirow{2}{*}{ Low } & \multirow{2}{*}{15 menit } & \multirow{2}{*}{43} & 1 & 0,6586 & 7,92 & \multirow{2}{*}{$7,72 \pm 0,28$} \\
\hline & & & 2 & 0,6148 & 7,52 & \\
\hline \multirow{10}{*}{ Medium } & \multirow{2}{*}{3 menit } & \multirow{2}{*}{38} & 1 & 0,5085 & 6,56 & \multirow{2}{*}{$6,69 \pm 0,18$} \\
\hline & & & 2 & 0,5367 & 6,82 & \\
\hline & \multirow{2}{*}{5 menit } & \multirow{2}{*}{46} & 1 & 0,6184 & 7,55 & \multirow{2}{*}{$7,72 \pm 0,23$} \\
\hline & & & 2 & 0,6551 & 7,88 & \\
\hline & \multirow{2}{*}{7 menit } & \multirow{2}{*}{57} & 1 & 0,8225 & 9,39 & \multirow{2}{*}{$9,18 \pm 0,30$} \\
\hline & & & 2 & 0,7755 & 8,97 & \\
\hline & \multirow{2}{*}{9 menit } & \multirow{2}{*}{61} & 1 & 0,6812 & 8,12 & \multirow{2}{*}{$8,23 \pm 0,15$} \\
\hline & & & 2 & 0,7051 & 8,33 & \\
\hline & \multirow{2}{*}{12 menit } & \multirow{2}{*}{73} & 1 & 0,7618 & 8,85 & \multirow{2}{*}{$8,77 \pm 0,11$} \\
\hline & & & 2 & 0,7444 & 8,69 & \\
\hline
\end{tabular}

Berdasarkan hasil tersebut diketahui kadar total fenol sangat dipengaruhi oleh waktu ekstraksi. Pada tipe pemanasan Medium, kadar total fenol semakin meningkat hingga menit ke-7 yaitu pada suhu $57{ }^{\circ} \mathrm{C}$ sehingga dihasilkan kadar total fenol optimum sebesar 9,18 $\pm 0,3 \%$. Suhu yang tinggi akan meningkatkan difusi ekstraktif pada struktur jaringan tanaman sehingga menghasilkan kadar total fenol yang tinggi. Namun, terlalu tingginya suhu dengan waktu ekstraksi yang lebih lama juga dapat menyebabkan degradasi senyawa yang terekstraksi (Hofmann et al., 2015). Hal ini dapat ditunjukkan pada penurunan kadar total fenol pada menit ke 9 yaitu menjadi $8,23 \pm 0,15 \%$.

Jika dibandingkan dengan hasil penelitian lainnya, kadar total fenol ekstrak temu kunci melalui ekstraksi maserasi adalah sebesar 8,245\% (Melannisa et al., 2011). Hal tersebut menunjukkan bahwa ekstraksi dengan bantuan microwave memiliki tingkat efisiensi yang lebih tinggi daripada ekstraksi maserasi karena dengan waktu ekstraksi microwave yang lebih sedikit dapat menghasilkan kadar total fenol yang lebih tinggi dibandingkan dengan proses ekstraksi maserasi. 


\section{Hasil Pengukuran Kadar Flavonoid}

Penetapan kadar flavonoid ditentukan dengan menggunakan metode kolorimetri aluminium klorida. Sampel yang direaksikan dengan aluminium klorida akan membentuk kompleks stabil dengan gugus karbonil pada $\mathrm{C} 4$ serta gugus hidroksil pada C3 dan C5 senyawa flavon dan flavonol. Selain itu, akan terbentuk pula kompleks labil dengan gugus ortohidroksil pada cincin A atau B dari flavonoid sehingga memberikan efek batokromik pada sampel (Almurdani et al., 2020; Lysiuk and Hudz, 2017; Thangaraj, 2016).

Pada penelitian ini, larutan standar yang digunakan adalah kuersetin dengan konsentrasi 0, 5, 10, 20, 30, dan $40 \mu \mathrm{g} / \mathrm{mL}$. Hasil pengukuran absorbansi larutan standar kuersetin pada panjang gelombang $510 \mathrm{~nm}$ dapat dilihat pada Tabel 4. Berdasarkan nilai absorbansi larutan standar kuersetin, dibuat kurva kalibrasi sehingga didapatkan persamaan garis linear $\mathrm{y}=0,0075 \mathrm{x}+0,039$, nilai koefisien determinasi $\left(\mathrm{R}^{2}\right)=0,9585$, dan koefisien korelasi $(\mathrm{r})=$ 0,979 (Gambar 2).

Tabel 4. Hasil pengukuran absorbansi larutan standar kuersetin.

\begin{tabular}{lccc}
\hline \multirow{2}{*}{ Konsentrasi $(\boldsymbol{\mu g} / \mathbf{m l})$} & \multicolumn{3}{c}{ Absorbansi ke- } \\
\cline { 2 - 4 } & $\mathbf{1}$ & $\mathbf{2}$ & Rata-Rata \\
\hline 0 & 0,0087 & 0,0098 & 0,0093 \\
5 & 0,0810 & 0,0679 & 0,0745 \\
10 & 0,1352 & 0,1312 & 0,1332 \\
20 & 0,2237 & 0,2226 & 0,2232 \\
30 & 0,2654 & 0,2644 & 0,2649 \\
40 & 0,3151 & 0,3194 & 0,3173 \\
\hline
\end{tabular}

Persamaan garis linear bermanfaat untuk menentukan kadar flavonoid dalam ekstrak temu kunci. Nilai $\mathrm{R}^{2}=$ 0,9585 memiliki arti 95,85\% absorbansi dipengaruhi oleh konsentrasi, sedangkan nilai $\mathrm{r}=0,979$ menunjukan terdapat hubungan yang erat antara konsentrasi dan absorbansi. Semakin besar konsentrasi maka absorbansinya akan semakin besar. Kadar flavonoid ekstrak temu kunci pada waktu ekstraksi 15 menit dengan tipe pemanasan

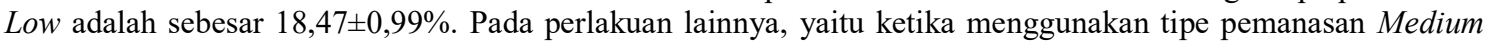
dengan waktu ekstraksi 3, 5, 7, 9, dan 12 menit, didapatkan kadar total fenol secara berurutan sebesar 13,46 $\pm 2,85$; $14,16 \pm 0,63 ; 21,41 \pm 0,13 ; 19,65 \pm 1,02$; dan $19,71 \pm 0,13 \%$ (Tabel 5).

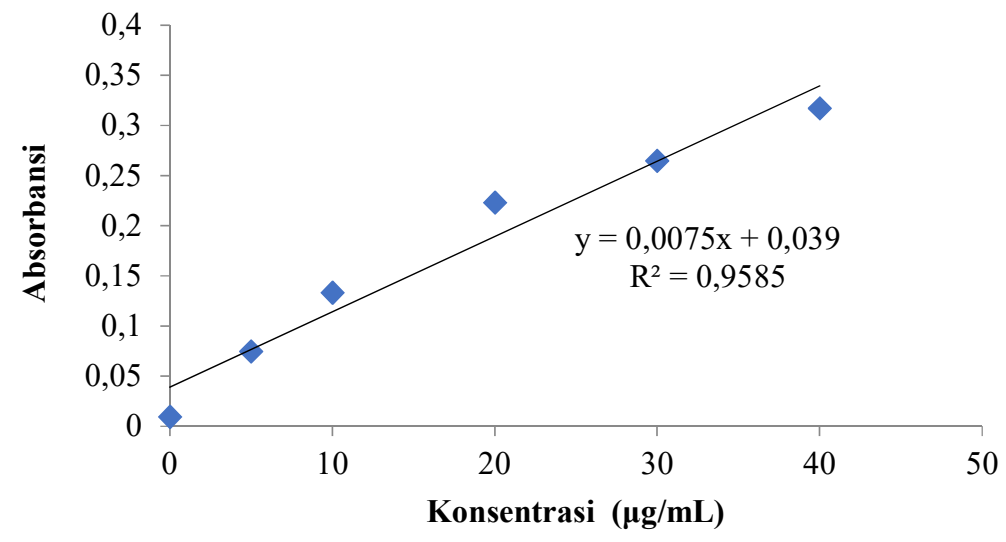

Gambar 2. Kurva kalibrasi larutan standar kuersetin pada panjang gelombang $510 \mathrm{~nm}$.

Berdasarkan hasil tersebut, diketahui bahwa kadar flavonoid ekstrak temu kunci sangat bergantung kepada waktu dan suhu ekstraksi yang digunakan. Kadar flavonoid tertinggi adalah pada waktu ekstraksi selama 7 menit

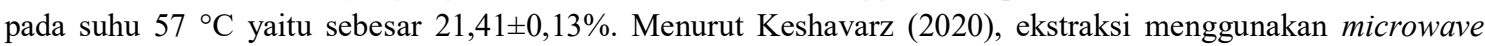
dengan waktu yang lebih singkat akan menghasilkan kadar flavonoid yang setara dengan ekstraksi menggunakan sonikasi dan pengaduk magnet selama 40 menit. Namun, pada penelitian ini kadar flavonoid mengalami penurunan pada menit ke-9 dan suhu $61{ }^{\circ} \mathrm{C}$ yaitu menjadi $19,65 \pm 1,02 \%$. Hal ini disebabkan karena senyawa flavonoid adalah senyawa yang termolabil sehingga akan terdegradasi pada suhu lebih dari $60^{\circ} \mathrm{C}$. 
Tabel 5. Kadar flavonoid ekstrak temu kunci melalui ekstraksi microwave pada beberapa waktu ekstraksi

\begin{tabular}{|c|c|c|c|c|c|c|}
\hline $\begin{array}{l}\text { Tipe } \\
\text { Pemanasan }\end{array}$ & $\begin{array}{l}\text { Waktu } \\
\text { Ekstraksi }\end{array}$ & $\begin{array}{l}\text { Suhu } \\
\left({ }^{\circ} \mathrm{C}\right)\end{array}$ & Ulangan & Absorbansi & $\begin{array}{c}\text { Kadar Flavonoid } \\
\text { Ekstrak (\%) }\end{array}$ & $\begin{array}{c}\text { Rerata Kadar } \\
\text { Flavonoid Ekstrak } \\
(\%)\end{array}$ \\
\hline \multirow{2}{*}{ Low } & \multirow{2}{*}{15 menit } & \multirow{2}{*}{43} & 1 & 0,1634 & 17,77 & \multirow{2}{*}{$18,47 \pm 0,99$} \\
\hline & & & 2 & 0,1732 & 19,17 & \\
\hline \multirow{10}{*}{ Medium } & \multirow{2}{*}{3 menit } & \multirow{2}{*}{38} & 1 & 0,1473 & 15,47 & \multirow{2}{*}{$13,46 \pm 2,85$} \\
\hline & & & 2 & 0,1191 & 11,44 & \\
\hline & \multirow{2}{*}{5 menit } & \multirow{2}{*}{46} & 1 & 0,1350 & 13,71 & \multirow{2}{*}{$14,16 \pm 0,63$} \\
\hline & & & 2 & 0,1412 & 14,60 & \\
\hline & \multirow{2}{*}{7 menit } & \multirow{2}{*}{57} & 1 & 0,1882 & 21,31 & \multirow{2}{*}{$21,41 \pm 0,13$} \\
\hline & & & 2 & 0,1895 & 21,50 & \\
\hline & \multirow{2}{*}{9 menit } & \multirow{2}{*}{61} & 1 & 0,1816 & 20,37 & \multirow{2}{*}{$19,65 \pm 1,02$} \\
\hline & & & 2 & 0,1715 & 18,93 & \\
\hline & \multirow{2}{*}{12 menit } & \multirow{2}{*}{73} & 1 & 0,1763 & 19,61 & \multirow{2}{*}{$19,71 \pm 0,13$} \\
\hline & & & 2 & 0,1776 & 19,80 & \\
\hline
\end{tabular}

Pada penelitian lainnya, kadar flavonoid temu kunci yang berasal dari metode ekstraksi maserasi adalah sebesar 24,71 mgQE/g (Hati et al., 2019). Hal tersebut menunjukkan bahwa kadar flavonoid yang dihasilkan oleh metode ekstraksi microwave adalah lebih kecil daripada yang dihasilkan oleh metode maserasi. Namun, ditinjau dari aspek waktu, ekstraksi dengan menggunakan microwave lebih efisien daripada maserasi karena hanya membutuhkan waktu ekstraksi yang jauh lebih sedikit dibandingkan dengan maserasi.

\section{KESIMPULAN}

Berdasarkan penelitian, dapat disimpulkan bahwa semakin lama waktu ekstraksi melalui metode ekstraksi microwave maka akan menghasilkan rendemen ekstrak temu kunci yang semakin tinggi. Selain itu, kadar total fenol dan flavonoid tertinggi yang diperoleh pada ekstrak temu kunci masing-masing adalah sebesar $9,18 \pm 0,30 \%$ dan $21,41 \pm 0,13 \%$ dengan menggunakan metode ekstraksi microwave tipe pemanasan Medium selama 7 menit pada suhu $57^{\circ} \mathrm{C}$.

\section{UCAPAN TERIMAKASIH}

Penulis mengucapkan terimakasih kepada Direktorat Jendral Penguatan Riset dan PengembanganKementerian Riset, Teknologi dan Pendidikan Tinggi Tahun Anggaran 2020 yang telah mendanai Penelitian Dosen Pemula (PDP) ini dengan Kontrak Penelitian Nomor: 079/SP2H/AMD/LT/DRPM/2020.

\section{DAFTAR PUSTAKA}

Ahmad, R. A., Juwita, and Ratulangi, S.A.D., 2015. Penetapan Kadar Fenolik dan Flavonoid Total Ekstrak Metanol Buah dan Daun Patikala (Ettingera elatior (Jack) R.M.SM). Pharmaceutical Sciences and Research 2(1), 1-10. doi: 10.7454/psr.v2i1.3481.

Almurdani, M., Zamri, A., Nugroho, T. T., Karim, J., Eryanti, Y., Hendra, R., and Teruna, H. Y., 2020. Antioxidant and Antidiabetic Activities of Mempening (Lithocarpus bancanus) Leaves. Pharmacognosy Journal 12(2), 328-334. doi: 10.5530/pj.2020.12.52.

Atun, S., Handayani, S., and Rakhmawati, A., 2018. Potential Bioactive Compounds Isolated from Boesenbergia rotunda as Antioxidant and Antimicrobial Agents. Pharmacognosy Journal 10(3), 513-518. doi: 10.5530/pj.2018.3.84.

Azmir, J., Zaidul, I. S. M., Rahman, M. M., Sharif, K. M., Mohamed, A., Sahena, F., Jahurul, M. H. A., Ghafoor, K., Norulaini, N. A. N., and Omar, A. K. M., 2013. Techniques for Extraction of Bioactive Compounds from Plant Materials: A review. Journal of Food Engineering 117(4), 426-436. doi: 10.1016/j.jfoodeng.2013.01.014.

Bastola, K. P., Guragain, Y. N., Bhadriraju, V., and Vadlani, P. V. 2017. Evaluation of Standards and Interfering Compounds in the Determination of Phenolics by Folin-Ciocalteu Assay Method for Effective Bioprocessing of Biomass. American Journal of Analytical Chemistry, 08(06), 416-431. doi: 10.4236/ajac.2017.86032.

Chahyadi, A., Hartati, R., Wirasutisna, K. R., and Elfahmi, 2014. Boesenbergia Pandurata Roxb., An Indonesian Medicinal Plant: Phytochemistry, Biological Activity, Plant Biotechnology. Procedia Chemistry 13, $13-37$. 
doi: 10.1016/j.proche.2014.12.003.

Dahmoune, F., Nayak, B., Moussi, K., Remini, H., and Madani, K., 2015. Optimization of Microwave-Assisted Extraction of Polyphenols from Myrtus communis L. Leaves. Food Chemistry 166, 585-595. doi: 10.1016/j.foodchem.2014.06.066.

Elboughdiri, N., 2018. Effect of Time, Solvent-Solid Ratio, Ethanol Concentration and Temperature on Extraction Yield of Phenolic Compounds from Olive Leaves. Engineering, Technology \& Applied Science Research 8(2), 2805-2808. doi: 10.48084/etasr.1983.

Ford, L., Theodoridou, K., Sheldrake, G. N., and Walsh, P. J. 2019. A Critical Review of Analytical Methods Used for the Chemical Characterisation and Quantification of Phlorotannin Compounds in Brown Seaweeds. Phytochemical Analysis, 30(6), 587-599. doi: 10.1002/pca.2851.

Gałuszka, A., Migaszewski, Z., and Namieśnik, J. A., 2013. The 12 Principles of Green Analytical Chemistry and The Significance Mnemonic of Green Analytical Practices. TrAC - Trends in Analytical Chemistry 50, 7884. doi: 10.1016/j.trac.2013.04.010.

Hati, A. K., Dyahariesti, N., and Yuswantina, R., 2019. Penetapan Kadar Flavonoid Dan Uji Aktivitas Antibakteri Ekstrak Sereh (Cymbopogon nardus) dan Temu Kunci (Boesenbergia pandurata Roxb) Terhadap Bakteri Streptococcus Mutans. Indonesian Journal of Pharmacy and Natural Product 2(2), 71-78. doi: 10.35473/ijpnp.v2i2.264.

Hilma, R., Gustina, N., and Syahri, J., 2020. Pengukuran Total Fenolik, Flavonoid, Aktivitas Antioksidan dan Antidiabetes Ekstrak Etil Asetat Daun Katemas (Euphorbia heterophylla, L.) Secara In Vitro dan In Silico Melalui Inhibisi Enzim a-Glukosidase. ALCHEMY Jurnal Penelitian Kimia 16(2), 240. doi: 10.20961/alchemy.16.2.40087.240-249.

Hofmann, T., Nebehaj, E., Stefanovits-bányai, É., and Albert, L., 2015. Antioxidant Capacity and Total Phenol Content of Beech (Fagus sylvatica L.) Bark Extracts. Industrial Crops \& Products 77, 375-381. doi: 10.1016/j.indcrop.2015.09.008.

Jitvaropas, R., Saenthaweesuk, S., Somparn, N., Thuppia, A., Sireeratawong, S., and Phoolcharoen, W., 2012. Antioxidant, Antimicrobial and Wound Healing Activities of Boesenbergia rotunda. Natural Product Communications 7(7), 909-912. doi: 10.1177/1934578x1200700727.

Kala, H. K., Mehta, R., Sen, K. K., Tandey, R., and Mandal, V., 2016. Critical Analysis of Research Trends and Issues in Microwave Assisted Extraction of Phenolics: Have We Really Done Enough. TrAC - Trends in Analytical Chemistry 85, 140-152. doi: 10.1016/j.trac.2016.09.007.

Kautsari, S. N., Purwakusumah, E. D., and Nurcholis, W., 2020. Profil Kromatografi Lapis Tipis Ekstrak Kunyit (Curcuma longa Linn) Segar dan Simplisia dengan Variasi Metode Ekstraksi. Media Farmasi 16(1), 65. doi: 10.32382/mf.v16i1.1403.

Keshavarz B. and Rezaei, K., 2020. Microwave- and Ultrasound-Assisted Extraction of Phenolic and Flavonoid Compounds from Konar (Ziziphus spina-christi) fruits. International Food Research Journal 27(1), 47-55.

Lamuela-Raventós, R. M. 2017. Folin-Ciocalteu Method for the Measurement of Total Phenolic Content and Antioxidant Capacity. Measurement of Antioxidant Activity and Capacity: Recent Trends and Applications, 107-115. doi: 10.1002/9781119135388.ch6.

Limsuwan, S. and Voravuthikunchai, S. P., 2013. Bactericidal, Bacteriolytic, and Antibacterial Virulence Activities of Boesenbergia pandurata (Roxb.) Schltr Extract Against Streptococcus pyogenes. Tropical Journal of Pharmaceutical Research 12(6), 1023-1028. doi: 10.4314/tjpr.v12i6.23

López-Perea, P., Guzmán-Ortiz, F. A., Román-Gutiérrez, A. D., Castro-Rosas, J., Gómez-Aldapa, C. A., Rodríguez-Marín, M. L., Falfán-Cortés, R. N., González-Olivares, L. G., and Torruco-Uco, J. G., 2019. Bioactive Compounds and Antioxidant Activity of Wheat Bran and Barley Husk in The Extracts with Different Polarity. International Journal of Food Properties 22(1), 646-658. doi: 10.1080/10942912.2019.1600543.

Lysiuk, R. and Hudz, N. 2017. Differential Spectrophotometry: Application for Quantification of Flavonoids in Herbal Drugs and Nutraceuticals. International Journal of Trends in Food and Nutrition, 1, e102.

Melannisa, R., Da'i, M., and Rahmi, T. R., 2011. Uji Aktivitas Penangkap Radikal Bebas dan Penetapan Kadar Fenolik Total Ekstrak Etanol Tiga Rimpang Genus Curcuma dan Rimpang Temu kunci (Boesenbergia pandurata). Pharmacon: Jurnal Farmasi Indonesia 12(1). doi: 10.23917/pharmacon.v12i1.47.

Ngibad, K. and Lestari, L. P. 2020. Aktivitas Antioksidan dan Kandungan Fenolik Total Daun Zodia (Evodia suaveolens). ALCHEMY Jurnal Penelitian Kimia 16(1), 94. doi: 10.20961/alchemy.16.1.35580.94-109.

Rajkovic, K. M., Stojic, S. S., Velic, D. T., Nada, C., Simic, V. M., Karabegovic, I. T., and Lazic, M. L., 2016. Optimization of Microwave-Assisted Extraction of Total Polyphenolic Compounds from Chokeberries by Response Surface Methodology and Artificial Neural Network. Separation and Purification Technology 
160, 89-97. doi: 10.1016/j.seppur.2016.01.019.

Sa'adah, H. and Nurhasnawati, H., 2015. Perbandingan Pelarut Etanol dan Air pada Pembuatan Ekstrak Umbi Bawang Tiwai (Eleutherine americana Merr) Menggunakan Metode Maserasi. Jurnal Ilmiah Manuntung 1(2), 149-153. doi: 10.51352/jim.v1i2.27.

Silve, A., Papachristou, I., Wüstner, R., Sträßner, R., Schirmer, M., Leber, K., Guo, B., Interrante, L., Posten, C., and Frey, W., 2018. Extraction of Lipids from Wet Microalga Auxenochlorella protothecoides Using Pulsed Electric Field Treatment and Ethanol-Hexane Blends. Algal Research 29, 212-222. doi: 10.1016/j.algal.2017.11.016.

Sukandar, E. Y., Fidrianny, I., and Kamil, A., 2015. In situ Antibacterial Activity of Kaempferia pandurata (Roxb.) Rhizomes Against Staphylococcus aureus. International Journal of Pharmacy and Pharmaceutical Sciences $7(2), 239-244$.

Sukandar E.Y. and Sunderam N., F., 2014. Activity of Kaempferia pandurata (Roxb.) Rhizome Ethanol Extract Against MRSA, MIRCNS, MISSA, Bacillus subtilis and Salmonella typhi. Pakistan Journal of Biological Sciences 17(1), 49-55. doi: 10.3923/pjbs.2014.49.55.

Thangaraj, P. 2016. Pharmacological Assays of Plant-Based Natural Products: Quantification of Secondary Metabolites. In Progress in Drug Research 71. Issue 2003, 49-55. doi: 10.1007/978-3-319-26811-8.

Vieira, V., Prieto, M. A., Barros, L., Coutinho, J. A. P., Ferreira, O., and Ferreira, I. C. F. R., 2017. Optimization and Comparison of Maceration and Microwave Extraction Systems for The Production of Phenolic Compounds from Juglans regia L. for The Valorization of Walnut Leaves. Industrial Crops and Products 107, 341-352. doi: 10.1016/j.indcrop.2017.06.012. 